\title{
JNPH
}

Volume 6 No. 2 (Oktober 2018)

(C) The Author(s) 2018

\section{PENGARUH CANGKANG KOPI SEBAGAI ADSORBEN DALAM MENURUNKAN KADAR BESI (Fe) PADA AIR SUMUR GALI}

\author{
THE EFFECT OF COFFEE SHELL AS AN ADSORBENT REDUCING IRON (Fe) \\ LEVELS IN DIG WELL WATER
}

\author{
RIANG ADEKO \\ POLITEKNIK KESEHATAN KEMENTERIAN KESEHATAN BENGKULU, JURUSAN \\ KESEHATAN LINGKUNGAN, \\ JALAN INDRAGIRI NOMOR 3 PADANG HARAPAN BENGKULU \\ E-mail : keslingpoltek@gmail.com
}

\begin{abstract}
ABSTRAK
Sumber air merupakan suatu komponen yang mutlak harus ada, karena tanpa sumber air sistem penyediaan air tidak akan berfungsi. Dengan mengetahui akan karakteristik masing-masing sumber air serta faktor-faktor yang mempengaruhi penyediaan air bersih. Pemakaian air bersih yang tidak memenuhi standar kualitas tersebut dapat menimbulkan gangguan kesehatan, baik secara langsung dan cepat maupun tidak langsung dan secara perlahan. Kadar besi maksimum yang diperbolehkan ada di dalam air minum menurut Permenkes Nomor 32 Tahun 2017 sebesar $1 \mathrm{mg} /$ liter. Jenis penelitian yang akan dilakukan aujdalah semi eksperimen (pre experiment), dengan rancangan penelitian pretest-posttest with control group ,data diperoleh melalui pengujian laboratorium, dengan jumlah sampel 3 dengan varian ketebalan yang berbeda $(20 \mathrm{~cm}$, $30 \mathrm{~cm}, 40 \mathrm{~cm}$ ), dianalisis dengan univariat dan penyajian distribusi frekuensi. Lokasi penelitian pada air sumur gali warga Kelurahan Rawa Makmur Permai Kota Bengkulu dan diteliti di bengkel kerja (Workshop) Jurusan Kesehatan Lingkungan Poltekkes Kemenkes Bengkulu. Hasil penelitian ini menunjukan bahwa adanya penuruanan kadar besi (fe) pada air sesudah dilakukannya penyaringan menggunakan karbon aktif cangkang kopi sebesar $10 \%$ pada setiap $10 \mathrm{~cm}$ ketebalan. Hasil penelitian diperoleh bahwa semakin tebal adsorben maka semakin efektif penurunannya.
\end{abstract}

\section{Kata Kunci: Sumur Gali, Cangkang kopi, Air Bersih}

\begin{abstract}
Water sources are an absolute component that must exist, because without a water source the water supply system will not function. By knowing the characteristics of each water source and the factors that influence the supply of clean water. The use of clean water that does not meet these quality standards can cause health problems, both directly and quickly and indirectly and slowly. The maximum iron content allowed in drinking water according to Permenkes No. 32 of 2017 is $1 \mathrm{mg} /$ liter. The type of research that will be conducted is semi-experimental (pre experiment), with a pretest-posttest with control group research design, data obtained through laboratory testing, with 3 samples with different thickness variants $(20 \mathrm{~cm}, 30 \mathrm{~cm}, 40 \mathrm{~cm})$, analyzed with univariate and presentation of frequency distribution. The location of the study
\end{abstract}


was the well water dug by the residents of the Rawa Makmur Permai Sub-District of Bengkulu City and was examined in a workshop (Workshop) of the Health Department of the Health Ministry of Health Polytechnic of Bengkulu. The results of this study indicate that there is a decrease in iron content in water after filtration using coffee shell activated carbon by $10 \%$ every $10 \mathrm{~cm}$ thickness. The results showed that the thicker the adsorbent, the more effective the reduction.

\section{Keywords: Dig Well, Coffee Shell, Clean Water}

\section{PENDAHULUAN}

Sumber air merupakan suatu komponen yang mutlak harus ada, karena tanpa sumber air sistem penyediaan air tidak akan berfungsi. Dengan mengetahui akan karakteristik masing-masing sumber air serta faktor-faktor yang mempengaruhi penyediaan air bersih serta mempermudah tahapan selanjutnya di dalam pemilihan tipe dari pengolahan untuk menghasilkan air yang memenuhi standar kualitas secara fisik, kimiawi dan bakteriologis (Soehartono, 2015).

Air tanah alias air sumur merupakan sumber air bersih terbesar yang digunakan. Permasalahan yang timbul yakni sering dijumpai bahwa kualitas air tanah maupun air sungai yang digunakan masyarakat kurang memenuhi syarat sebagai air bersih yang sehat bahkan di beberapa tempat bahkan tidak layak untuk digunakan. Air yang layak digunakan, mempunyai standar persyaratan tertentu yakni persyaratan fisik, kimiawi dan bakteriologis, dan syarat tersebut merupakan satu kesatuan. Jadi jika ada satu saja parameter yang tidak memenuhi syarat maka air tesebut tidak layak untuk digunakan. Pemakaian air bersih yang tidak memenuhi standar kualitas tersebut dapat menimbulkan gangguan kesehatan, baik secara langsung dan cepat maupun tidak langsung dan secara perlahan (Saleh, 2016).

Besi adalah elemen kimiawi yang dapat ditemukan hampir disetiap tempat dibumi pada semua lapisan-lapisan geologis dan badan air. Besi dalam air tanah dapat berbentuk Fe (II) dan Fe(III) terlarut. Fe (II) terlarut dapat tergabung dengan zat organic membentuk suatu senyawa kompleks
(Jubilate, 2016). Kadar besi maksimum yang diperbolehkan ada di dalam air minum menurut Permenkes Nomor 32 Tahun 2017 sebesar $1 \mathrm{mg} /$ liter (Permenkes RI, 2017).

Senyawa besi dalam jumlah kecil di dalam tubuh manusia berfungsi sebagai pembentuk sel-sel darah merah, dimana tubuh memerlukan 7-35 $\mathrm{mg}$ /hari yang sebagian diperoleh dari air. Tetapi zat Fe yang melebihi dosis yang diperlukan oleh tubuh dapat menimbulkan masalah kesehatan. Hal ini dikarenakan tubuh manusia tidak dapat mengsekresi $\mathrm{Fe}$, sehingga bagi mereka yang sering mendapat tranfusi darah warna kulitnya menjadi hitam karena akumulasi $\mathrm{Fe}$ (Adeko, 2017).

\section{METODE PENELITIAN}

Jenis penelitian yang akan dilakukan aujdalah semi eksperimen (pre experiment), dengan rancangan penelitian pretest-posttest with control group (Notoadmodjo, 2010)

Lokasi penelitian pada air sumur gali warga Kelurahan Rawa Makmur Permai Kota Bengkulu dan diteliti di bengkel kerja (Workshop) Jurusan Kesehatan Lingkungan Poltekkes Kemenkes Bengkulu dengan alokasi waktu penelitian selama 2 bulan.

\section{HASIL PENELITIAN}

Hasil penyaringan dengan media karbon aktif cangkang kopi dalam menurunkan besi (fe) pada sumur gali dengan menggunakan metode SSA (Spektrofotometri Serapan Atom)

Tabel 4.1 Diatribusi Penyerapan kadar Fe pada Cangkang Kopi 


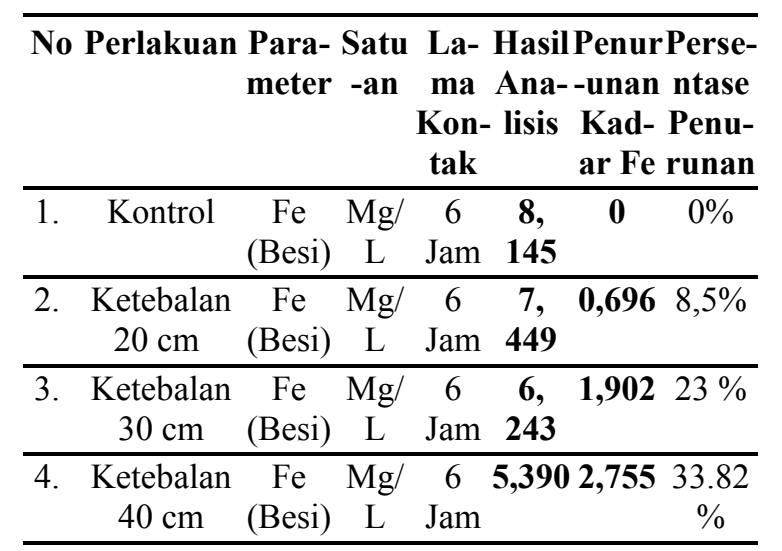

Dari tabel di atas dapat diketahui dari kontrol yang tidak melalui penyaringan cangkang kopi 8, $145 \mathrm{Mg} / \mathrm{L}$ dan dari berbagai variasi ketebalan cangkang kopi bisa menyerap $1 \mathrm{Mg} / \mathrm{L}$ kadar besi di dalam sumur gali.

\section{PEMBAHASAN}

Air yang layak digunakan, mempunyai standar persyaratan tertentu yakni persyaratan fisik, kimiawi dan bakteriologis, dan syarat tersebut merupakan satu kesatuan. Jadi jika ada satu saja parameter yang tidak memenuhi syarat maka air tesebut tidak layak untuk digunakan. Pemakaian air bersih yang tidak memenuhi standar kualitas tersebut dapat menimbulkan gangguan kesehatan, baik secara langsung dan cepat maupun tidak langsung dan secara perlahan (Saleh, 2016).

Cangkang kopi adalah kulit buah yang terbentuk karena proses pengelupasan untuk mendapatkan biji kopi tanpa kulit. Jumlah cangkang kopi sebanyak 55\% dari jumlah buah kopi yang dihasilkan, sehingga menyebabkan banyaknya cangkang kopi yang bertumpuk menjadi limbah karena ketidak tahuan masyarakat untuk memanfaatkan nya kembali. Disini peneliti membuat cangkang kopi yang tidak dimanfaatkan menjadi carbon cangkang kopi yang bisa menurunkan kadar besi (fe) pada sumur gali.

Hasil penelitian yang telah dilakukan peneliti pada tanggal 15 Mei 2018, yang telah diuji di UPT Laboratorium Lingkungan untuk hasil penyaringan dengan variasi ketebalan karbon cangkang kopi $20 \mathrm{~cm}$ didapatkan hasil
$7,449 \mathrm{mg} / \mathrm{L}$, Ketebalan cangkang kopi $30 \mathrm{~cm}$ dengan hasil kandungan besi (fe) $6,243 \mathrm{mg} / \mathrm{L}$, dan ketebalan cangkang kopi $40 \mathrm{~cm}$ yaitu 5,390 mg/L. Jadi diketahui bahwa karbon cangkang kopi dapat menurunkan kadar besi di Rawa Makmur Permai kota Bengkulu dari air yang mengandung $\mathrm{Fe}$ sebanyak $8,145 \mathrm{mg} / \mathrm{L}$.

\section{KESIMPULAN}

Berdasarkan penelitian yang telah dilakukan di Rawa Makmur Permai kota Bengkulu dan pemeriksaan dilakukan di UPT Laboratorium Lingkungan kota Bengkulu dapat disimpulkan :

1. Hasil daya adsorbsi dengan ketebalan karbon cangkang kopi $20 \mathrm{~cm}$ sebesar 8,5\%.

2. Hasil daya adsorbsi dengan ketebalan karbon cangkang kopi $30 \mathrm{~cm}$ sebesar $23 \%$.

3. Hasil daya adsorbsi dengan ketebalan karbon cangkang kopi $40 \mathrm{~cm}$ sebesar $33.82 \%$.

4. Hasil air sumur gali tanpa perlakuan yaitu $0 \%$.

\section{SARAN}

1. Penelitian ini dapat digunakan sebagai media pembelajaran mahasiswa khususnya mata kuliah PAPLC

2. Untuk penelitian lebih lanjut dapat Dapat menjadi pertimbangan untuk penelitian sejenis dengan massa waktu dan ketebalan yang berbeda-beda.

\section{DAFTAR PUSTAKA}

Adeko, 2017. Penurunan Kadar Besi (Fe) Dan Mangan (Mn) Dengan Kombinasi Limbah Batubara Dan Limbah Tempurung Kemiri Di Sumur Gali Warga Padang Serai Kota Bengkulu. Bengkulu. Poltekkes Kemenkes Bengkulu.

Notoadmodjo, 2010. Notoatmodjo, S. 2010. Metodologi Penelitian Kesehatan. Jakarta : Rineka Cipta

Permenkes RI Nomor 32 Tahun 2017. 
Tentang Baku Mutu Kesehatan

Lingkungan dan Persyaratan Kesehatan

Air Untuk Keperluan Higiene Sanitasi,

Kolam Renang, Solus Per Aqua dan

Pemandian Umum.

Saleh. 2016. Penurunan Kadar Besi (Fe)

Pada Air Sumur Gali. Surabaya: Institut Teknologi Surabaya.

Soehartono. 2015. Penjernihan Air Dengan

Saringan Pasir Dan Desinfektan Alami.

Semarang : Universitas Pandanaraan. 